\title{
Lack of Moral Values in Indonesian Music Entertainment in the Post-Modern Era
}

\author{
Desti Kurniasari, S.Pd ${ }^{1, *}$ Dr. Drs. AM. Susilo Pradoko, M.Si. ${ }^{1}$ \\ ${ }^{1}$ Yogyakarta State University, Yogyakarta, Indonesia \\ "Corresponding author. Email: destikurniasari21@gmail.com
}

\begin{abstract}
This is a qualitative study that examines the phenomena in Indonesian music entertainment from the moral aspect and presents the importance of filtering television and internet broadcasting. The participants of this study were selected in accordance with the topic of this study. The results showed that in 2018, $45.3 \%$ of the total internet users accessed film or video content in the form of documentaries, short films, and music videos including those with vulgar content. Music entertainment is currently dominated by various negative treats, such as vulgar and sensual shows which tend to show someone's body part sensually for all viewers.
\end{abstract}

\section{Keywords: Music, Moral, Postmodern}

\section{INTRODUCTION}

We have come to the post-modern era which is presented by the development of technology and media globalization. Media globalization makes society more open. It includes the process of mass exchange of information which tends to be unlimited [1]. Information from around the world is globally dispersed and seems to dissolve. The absence of a limit to the dissemination of this information has led to changes in various affected nations, including Indonesia. One of the various fields affected by this globalization is the field of art, specifically music [2].

In this postmodern era, in creating music (songs), artists only consider the aspect of the market or trends currently developing in the society. There is no more ideology considered in the process of making music. Unfortunately, this leads to the absence of meaningful and beautiful languages, and sentences in the lyric. Some songs are made for fun and for the sake of other purposes. Several works also vary according to the creator and team, but not all song creators or singers take moral values into account. Some popular singers, for example, Duo Macan and Duo Semangka show vulgar performances in terms of costumes, dances, and song titles. Music entertainment which then was public consumption is now a stage of moral degradation especially when the audience is children or adolescents.
Based on data from Nielsen Indonesia or Nielsen Company through Databoks Katada, $97 \%$ of the total generation $\mathrm{Z}$ or adolescents aged 10-14 years in Indonesia watch television. At their ages, they are not able to choose whether something is a good or bad influence. They tend to imitate all what they see although it brings negative impacts. They are in the age of looking for an identity. People should present good entertainment with moral values for them. Moreover, parents do not clearly understand the concept of the entertainment rating system, for example, PG (Parental Guidance), NC017 (Adults Only), and R (Restricted, under 17 requires a parent or adult guardian company to watch). The phenomena indicate that children are prone to entertainment not suitable for their ages.

According to research entitled "Psychologists Study Media Violence for Harmful Effects" published by Psychological Association (APA) in 1995, good quality shows will influence someone (children) to behave well, and less qualified shows will lead to bad behaviors [16]. The moral formation is very important for human life, especially for young generations. The moral formation also refers to what is commonly witnessed or what is seen, both in the environment and from the internet. Therefore, researchers are interested in conducting a study on the presentation of Indonesian music in the Postmodern Era. 


\section{LITERATURE REVIEW}

\subsection{Post-Modern Era}

The postmodern era is characterized by the development of technology and media globalization. Media globalization has made society more open. Postmodernism is a new era that emerged at the end of the modern era [4]. First appeared in 1970 and was initiated by Jean Francois through his book entitled "The Postmodern Condition: A Report on Knowledge". Postmodernism is defined as criticism and rejection of modernism [5].

Postmodernism is also defined as a new perspective that functions as an alternative to modernism. Postmodernism appears as a reflection of distrust towards modernism which is considered to have failed to advance humans [6]. The development of technology with a positive impact has actually caused disruption and destruction during the modern era.

Based on this theory, postmodern is an era that firmly rejects all theories and ideas that developed in the previous era because it is considered a failure and has failed to advance people's ideas and nobility.

\subsection{Music}

Music is one of the branches of art that deals with structured or organized sound which has elements of melody, rhythm, and harmony, so it can be understood by humans [7]. Music also means a creation that represents the feelings of the creator [7].

Music is a medium of communication between humans [8]. Listening to music is a process of interaction between humans. Listening to music also contains the process of perceiving what the creators try to convey to listeners. Nowadays, music works are in the form of fancy songs because they are more attractive in terms of language, sentence structure, and musical sequences. Musical and literary elements in a song can attract people because basically, every human being is attracted to the beauty of the art of sound) [9].

\section{RESEARCH METHOD}

This is a qualitative descriptive study, which intends to examine the phenomena of Indonesian music entertainment from the perspective of moral value [10]. The participants of this study were Indonesian music performers chosen in accordance with the topic of this study. The data were collected through interviews and literature studies related to the topic discussed. The collected data were then described in sentences and analyzed through data reduction, data presentation, and conclusion drawing [11].

\section{RESULT AND DISCUSSION}

The moral formation is very important for human life, especially for the young generations. Moral formation refers to what is commonly witnessed or what is seen, both in the environment and from the internet. People are always engaged with musical performances, and they cannot avoid those with vulgar content.

Music with negative contents is free to be seen by everyone. As one of the impacts of globalization, various media present music performances without considering the rating system based on ages. Social media as the reflection of the digital era has become the main media for music performances. Instagram, Facebook, Tik Tok, and YouTube freely broadcast music without any filtering as shown in the picture. 1 and 2.

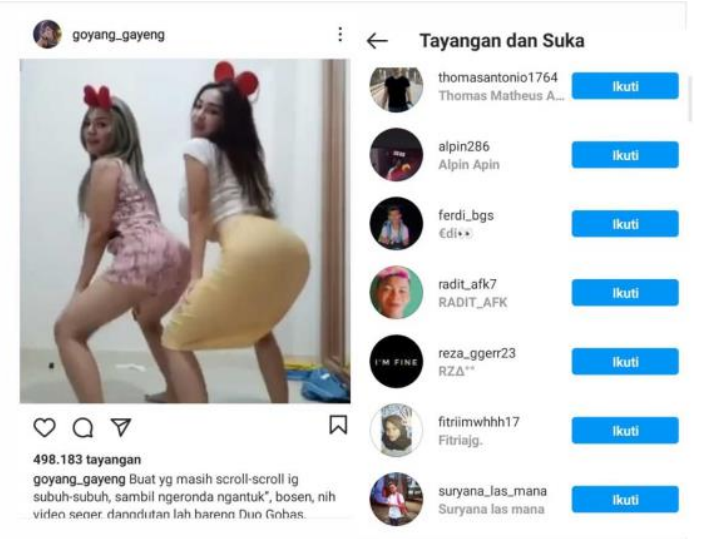

Figure 1 Duo Serigala performing in social media [12]

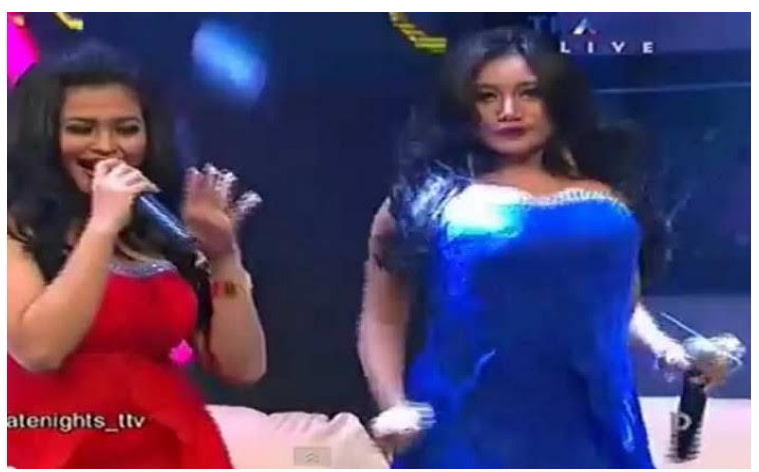

Figure 2 Duo serigala performing live in a television program [13]

The music video is uploaded to the Instagram platform and has been viewed nearly 500 thousand times. Using this data, 30 Instagram accounts were randomly selected and then the age of the account owners were analyzed. It was found that 10 of the 30 Instagram accounts were owned by children and teenagers. They were not at the age to enjoy that kind of video. This proves that listener appreciation is not based only on the music performed, but also based on 
the controversial contents. Besides the performer costume, the songs and dances are too vulgar, thus not suitable for children, teenagers, or even adults.

\subsection{Music Entertainment in Local Area}

Local music performances are influenced by the phenomenon of vulgar music. There are many performers in other areas who try to imitate this kind of performance from the way they sing, dress, and dance on the stage as seen from Figure 3 below.

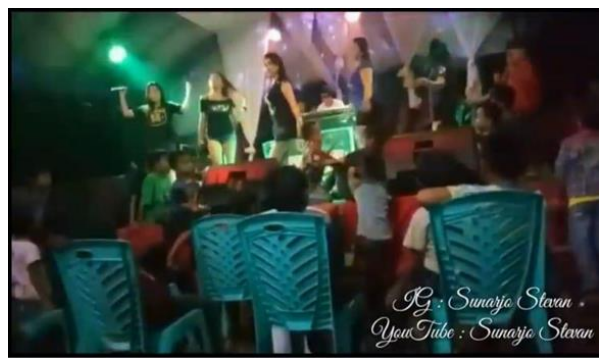

Figure 3 Music performance in Majene [14]

The electone music program was performed in front of many audiences in the Majene area. It can be seen that most of the audiences were children. The figure above shows that there was no age limit for the audiences. This kind of entertainment showed performers with inappropriate costumes in which the purpose was gaining popularity without considering the impacts on the audience moral. This seems normal that in this day and age, music entertainment is underestimated by many people since the performers tend to ignore moral values.

In presenting good entertainment, people should consider the content or lyrics. The entertainer should show quality. Duo Serigala, a dangdut singer group, performs in sensual clothes and dance. It is a shame, especially since Duo Serigala is a famous duo artist. Many dangdut artists (singers) continue to exist even though they do not do so, as these artists uphold their quality in singing. The public as music lovers should also be able to filter out quality broadcasts. People need to change their perceptions of quality and poor forms of music entertainment.

\subsection{The Importance of Broadcast Filtering}

According to the Internet Service Providers Association Survey/APIJI survey data, the number of internet users in Indonesia in 2018 was around 171.7 million out of 246.16 million Indonesian people in total. This number can certainly increase considering that there is a difference of two years with the current period. Based on these data, it shows how fast the use of the internet and social media is today as seen in Table 1.

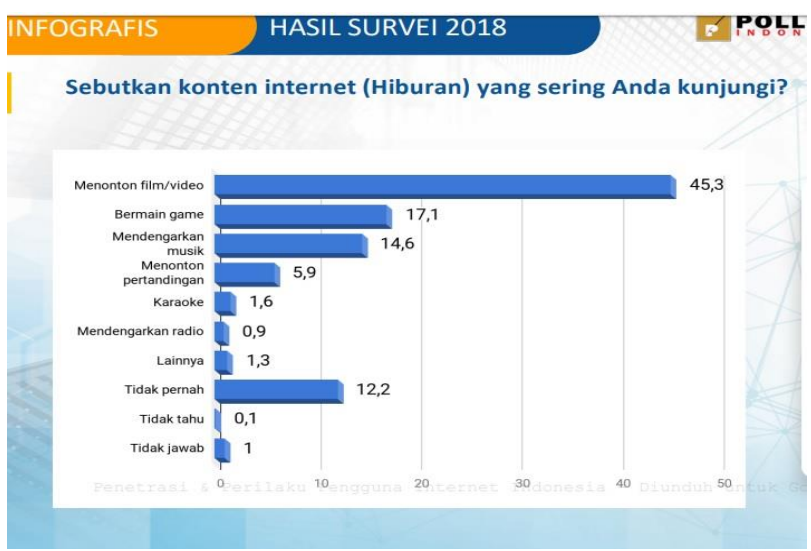

Table 1 Internet users in 2018

As many as $45.3 \%$ of total 2018 internet users access film or video content. These films can be in the form of documentaries and music videos including those of vulgar music videos. These data show how dangerous it is if music shows on the internet and social media are not filtered based on audience age. The young generation's morals will be affected because the vulgar music shows are not only shown on social media but also TV programs.

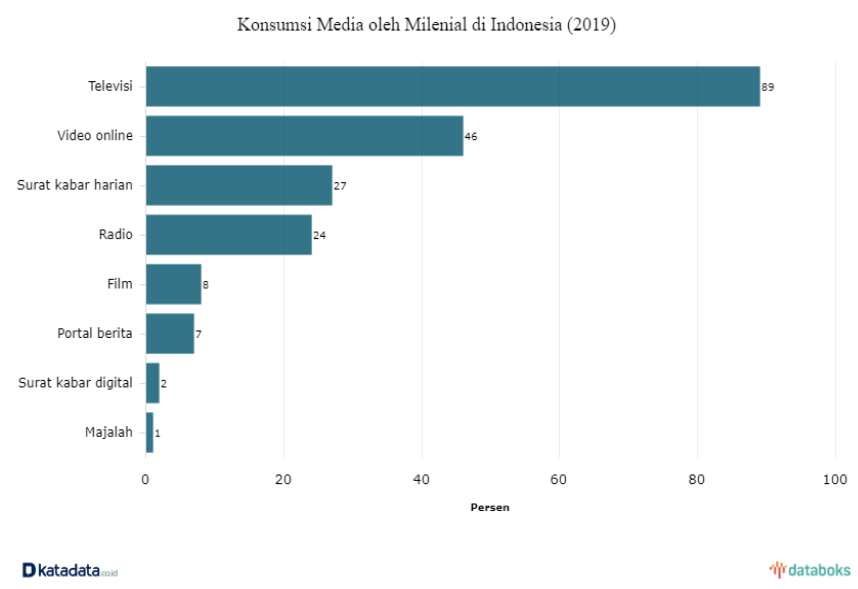

Table 2 TV audiences in 2019 [15]

According to Katada.co.id data in table 2, the number of teenage television users is $89 \%$ of the total Indonesian teenagers. Similar to the social media limit, the tv audiences should also be limited based on age. Most people think that TV shows are more about entertainment, so there is neither positive nor negative content in them. Unfortunately, music shows on television are infiltrated by vulgar shows.

Based on the explanation above, it is important to filter shows broadcast from both television and the internet. Parents have a vital role in limiting the TV shows that children may watch. Limiting the use of smartphones may also become a solution. Moreover, the government also needs to strictly filter all forms of broadcast on television as well as the internet and to not grant broadcasting permits for unqualified 
content. After all, it is the duty of all parties, including music performers, to show entertainment with good content only.

\section{CONCLUSION}

Music entertainment is currently dominated by various negative content such as vulgar and sensual shows. This is one of the impacts of the development of the postmodern era. Globalization has made the media expand resulting in music shows with vulgar content. As the music shows are broadcasted freely on TV and social media, children and adolescent are free to watch them. Therefore, it is necessary to limit the broadcast age and renew the public's perception of quality music. All parties, government, parents to music presenters, are responsible for monitoring the broadcast.

\section{REFERENCES}

[1] Sutiyono, Seni Tradisional Dalam Arus Globalisasi Ekonomi [Traditional Art in the Flow of Economic Globalization], Jurnal Cakrawala Pendidikan, Vol. 3 (1994): 18. DOI: 10.21831/cp.v3i3.9132

[2] Dewatara, Gerry Wahyu, and Sari Monik Agustin. Pemasaran musik pada era digital: Digitalisasi industri musik dalam industri 4.0 di Indonesia [Music marketing in the digital era: Digitalization of the music industry in industry 4.0 in Indonesia]. Jurnal WACANA 18.1 (2019): 5. DOI: 10.32509/wacana.v18i1.729

[3] McQuail, Denis, Teori Komunikasi Massa McQuail, Edisi 6 Buku 1[McQuail's Theory of Mass Communication, Issue 6 of Book 1]. Jakarta: Salemba Humanika, (2011): 43.

[4] Pawitro, Udjianto. Fenomena Post-Modernisme dalam Arsitektur Abad ke-21 [The Phenomenon of Post-Modernism in 21st Century Architecture], Jurnal Rekayasa, Vol. 14, No. 1 (2010): 42

[5] Supriadi, Postmodernisme [Postmodernism], Jurnal Spektrum Komunikasi, Vol. 5 No. 2 (2017): 108

[6] Setiawan, Johan, and Ajat Sudrajat. Pemikiran postmodernisme dan pandangannya terhadap ilmu pengetahuan [Postmodernism and Its Views of Science]. Gadjah Mada University, (2018): 29. DOI: $10.22146 /$ jf.33296

[7] Irnanningrat, Sang Nyoman Satria. Peran Kemajuan Teknologi Dalam Pertunjukan Musik [The Role of Technological Advances in Music Performance] INVENSI (Jurnal Penciptaan dan
Pengkajian Seni) $2.1 \quad$ (2017): 2. DOI: 10.24821/invensi.v2i1.1802

[8] Silaen, H.T. Pergeseran Fungsi Musik Di Tengah Kehidupan Masyarakat [The Shift in Function of Music in the Middle of Life Community]. Jurnal Cakrawala Pendidikan 3.3 (1995): 31.

[9] Aesijah, Siti. Latar Belakang Penciptaan Seni [Background of Creative Art].Harmonia: Journal of Arts Research and Education 1.2 (2000): 71. DOI:10.15294/harmonia.v1i2.845.

[10] Sunarto, Sunarto. Negativitas Total: Kritik Adorno terhadap Rasionalitas dan Seni Masyarakat Modern. Pelataran Seni 1.2: 143. DOI:10.20527/jps.v1i2.1883.

[11]Dewatara, Gerry Wahyu, and Sari Monik Agustin. Pemasaran musik pada era digital: Digitalisasi industri musik dalam industri 4.0 di Indonesia [Music marketing in the digital era: Digitalization of the music industry in industry 4.0 in Indonesia]. Jurnal WACANA 18.1 (2019): 5. DOI:10.32509/wacana.v18i1.729.

[12]Goyang, Gayeng [@ goyang_gayeng]. (n.d.). Posts [Instagram profile]. Instagram. Retreived January 16, 2020, from https://instagram.com/goyang_gayeng/

[13] Rayendra, Panditio. Tampilkan Duo Serigala Goyang Dribble Tengah Malam, KPI Tegur Trans TV [Showcasing Duo Serigala performimg Goyang Dribble at midnight, KPI reprimand Trans TV]. Tabloidbintang.Com, 10 Apr. 2015, www.tabloidbintang.com/film-tvmusik/kabar/read/20427/tampilkan-duo-serigalagoyang-dribble-tengah-malam-kpi-tegur-trans-tv.

[14] Stevan, Sunarjo. All Artis Electone Majene. YouTube, uploaded by Sunarjo Stevan, 3 Jan. 2018,

www.youtube.com/watch?v=txgKhUZvO1s\&fea ture=youtu.be.

[15] Lidwina, Andrea. Televisi, Media Paling Banyak Dikonsumsi Milenial Indonesia [Television, the Most Consumed Media for Indonesian Millennials]. katadata, 16 Jan. 2020, databoks.katadata.co.id/datapublish/2020/01/16/t elevisi-media-paling-banyak-dikonsumsimilenial-indonesia.

[16] American Psychology Association. Psychologists Study Media Violance for Harmful Effects. (2015). 